so there are not many authorities available and much of the challenge lies in ingenuity of reasoning.

I certainly intend to use the cases again and thought the Society, as well as Judge Jessup, might be interested in hearing of the uses to which they have been put in at least this law school.

Joseph MODESTE SWEeney Tulane Law School

\title{
TO THE EDITOR-IN-ChIEF
}

February 14, 1977

I would like to respond to the letter of Mr. Perry Pickert who commented on my article in the July 1976 issue of the Journal. ${ }^{1}$ Referring to Article 26 of the Treaty of Peace with Japan of September $8,1951,{ }^{2}$ he asserted that "even today, Japan lives under the threat of a unilateral unconditional mostfavored-nation clause." 3 Such an assertion is quite misleading and stands in the way of a proper understanding of the problem I tried to describe, for it ignores the actual situation of Japan under the Peace Treaty.

First, while I spoke of the "historical significance" of the unilateral clause as the typical pattern of treaty provision concluded in certain relationships between states until the 19th century, I never stated, and had no intention of implying, that such a clause is nonexistent today. Such an implication is contradicted by the remainder of my article. I am fully aware that similar clauses still exist under exceptional circumstances (such as navigation provisions in a treaty concluded with a landlocked state and certain peace-settlement provisions imposed upon the defeated in peace treaties). However, these examples cannot legitimately be construed as the typical treaty practice, the characteristics of which I described in the first paragraph of my article and footnotes 1 to 3 .

Moreover, it should be noted that the second sentence of Article 26 of the Peace Treaty quoted by Mr. Pickert has substantially lost its operative effect since the conclusion of the Joint Declaration with the Soviet Union of October 19, $1956^{4}$ and the Joint Communiqué with the People's Republic of China of September $29,1975^{5}$ (which replaced the Treaty of Peace with the Republic of China of April 28, 1952 ${ }^{\circ}$ ), in both of which peace has been restored and war claims have been waived, even though they are not peace treaties in form. In other words, the said provision now bears no practical significance and the application thereof is realistically inconceivable. After a dozen decades since Commodore Perry, it seems obvious that the change in the international environment has been so fundamental that one cannot compare that era with the present simply by pointing out the formal existence of a similar treaty provision.

Shinya Murase

To The EdTor-IN-ChieF

April 26, 1977

The piercing eye and pointed pen of the very erudite Prof. Julius Stone could find nothing useful in the consensus definition of aggression. ${ }^{1}$ His criticism of the defects and deficiencies are well taken but at the risk of

\footnotetext{
1 The Most-Favored-Nation Treatment in Japan's Treaty Practice During the Period 1854-1905, 70 AJIL 273 (1976).

23 UST 3169, TIAS No. 2490, 136 UNTS 45, at 75.

370 AJIL 816 (1976). 4263 UNTS 99.

517 The Japanese Annual of International Law 81 (1973).

6138 UNTS 3.

${ }^{1}$ Hopes and Loopholes in the 1974 Definition of Aggression, 71 AJIL 224 (1977).
} 
merely confirming his impression that I am a dreamer may I respectfully invite consideration to some positive aspects of the UN action.

The primary significance of the definition, which admittedly is vague and unenforceable, is that it symbolizes and encourages a determination and a direction which is persistent and irreversible. No matter how slow or erratic the progress may be there is an unmistakable and an unrelenting striving for a peaceful society in which aggression is controlled through collective action of the international community. The definition demonsstrates that even career diplomats, who were bound to consider above all else the interests of their own homeland, were unable to disregard the more pervasive universal demand for change. As the old order gives way to the new, the machinery of accommodation is bound to contain imperfections. That is hardly cause for unbridled denunciation or despair.

Over 25 years ago the United Nations declared that it would not resume work on a Code of Offenses Against the Peace and Security of Mankind or an International Criminal Court until aggression was defined. That obstacle has been removed and the attainment of a goal which Prof. Stone shares has become more feasible. ${ }^{2}$

Surely the learned professor, for whom I have the highest regard, does not wish to be considered either a scoffer or a cynic but only a realist. What he views as my "optimism which verges sometimes on wishfulness" 3 is merely a reflection of my determination that, no matter how tortuous may be the road, realism should never be so barbed as to discourage us, or those who come after us, from striving for the fulfillment of "scholarly dreams." 4

Benjamin B. Ferencz

To THE EdTTOR-IN-ChIEF

January 24, 1977

In his otherwise excellent analysis of recent events in the Western Sahara, ${ }^{1}$ Thomas Franck disapprovingly asserts that the U.S. support for the Moroccan-Mauritanian position of historic title "can only be understood as an act of political expediency." Approvingly, he adds that "[a]mong African states . . . a considerable number voted on principle rather than politics" ${ }^{2}$ when they supported self-determination for the territory's indigenous population.

It should be clear, however, that the principle these African states supported was politics and political expediency. As Professor Franck himself points out, "African states have insisted that each colony, in the final stage of decolonization, must exercise its 'right' of self-determination within the confines of established boundaries." ${ }^{3}$ To advocate otherwise, of course, would be to sanction and even invite the political dismemberment of virtually every independent African state.

\section{Tennessee Technological University}

\footnotetext{
2 See Stone \& Wetzel (eds.), Toward a Feastble International Criminal, Court (1970); reviewed in 66 AJIL 214 (1972).

${ }^{3}$ Supra note 1, at 242 . See also 70 AJIL 850.

4 See supra note 1 , at 241.

1 The Stealing of the Sahara, 70 AJIL 694-721 (1976).

2 Id. 718 . $\quad 3$ Id. 698.
} 